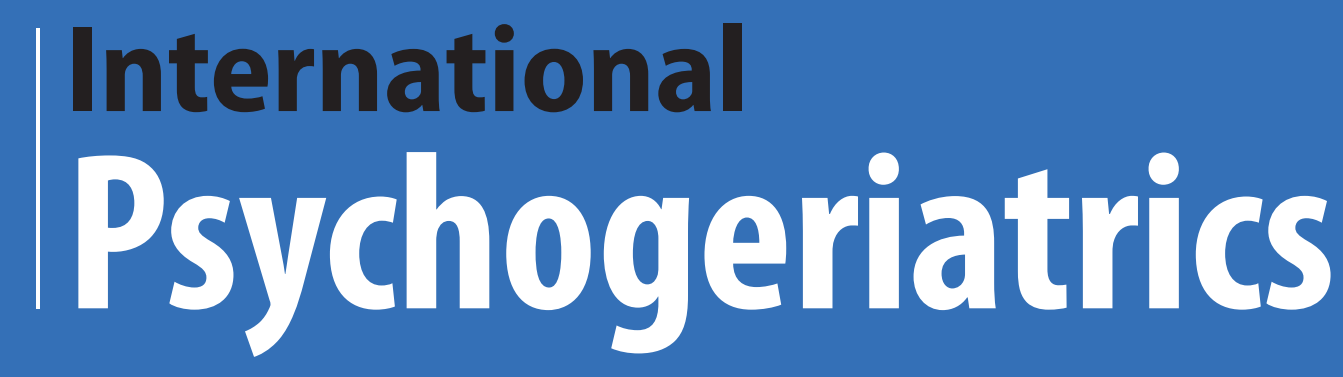

| journals.cambridge.org/ipg

The Official Journal of the
International Psychogeriatric Association
Better Mental Health for Older People

Issue Theme: Assessment of Cognitive Impairment in East Asia
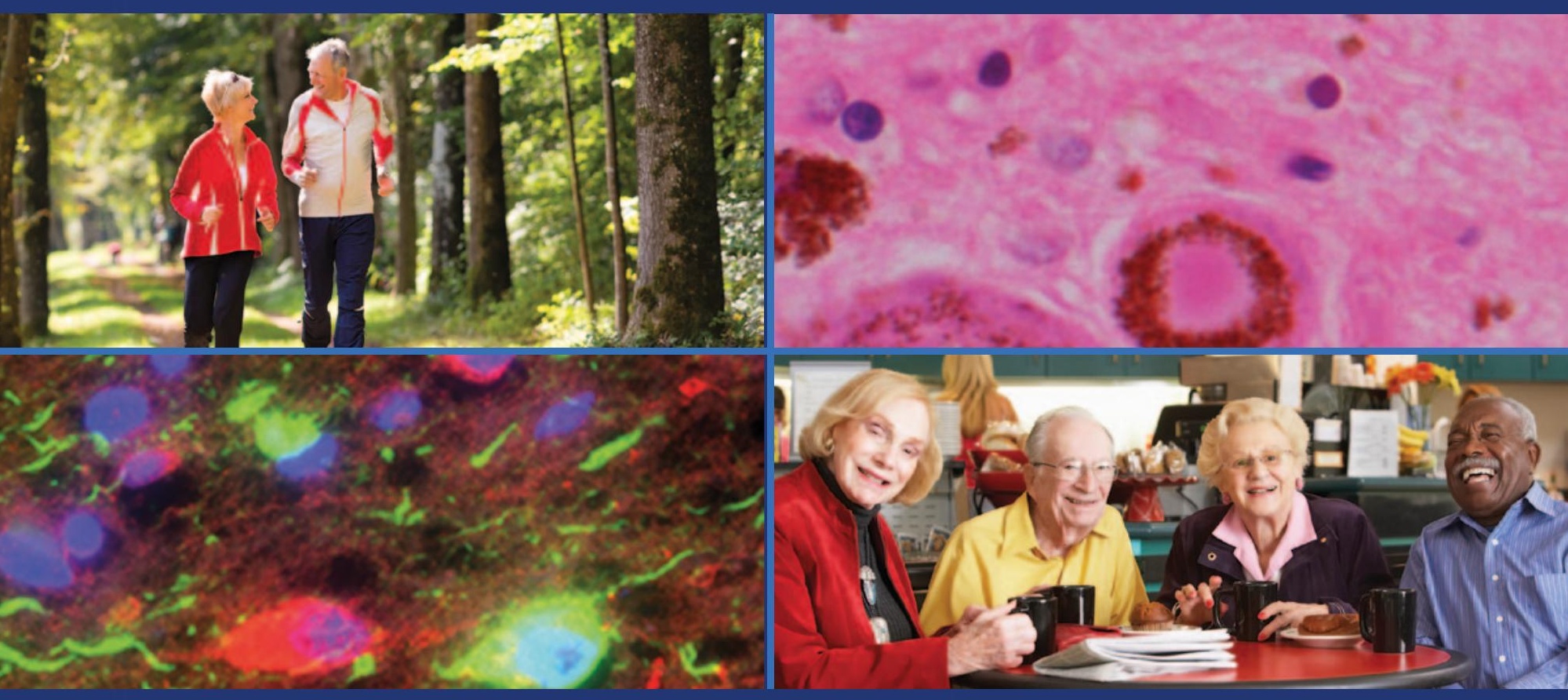


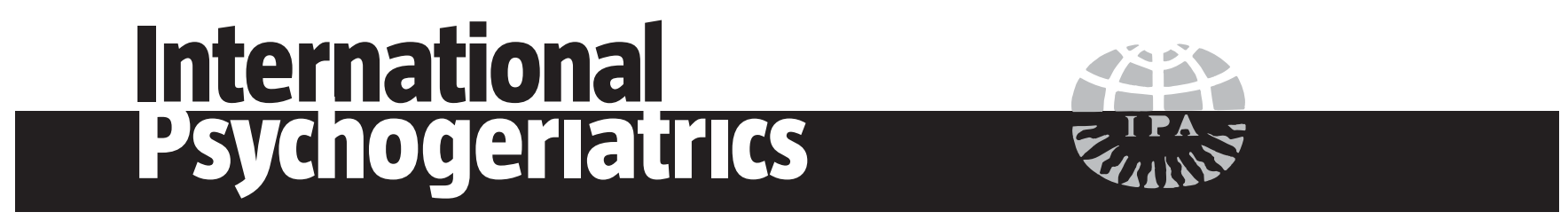

\section{Editorial Panel}

EDITOR-IN-CHIEF

Dilip V. Jeste

San Diego, CA, USA

DEPUTY EDITORS

Henry Brodaty

Sydney, Australia

Gill Livingston

London, UK

Kostas Lyketsos

Baltimore, MD, USA

STATISTICAL EDITOR

Stephan Arndt

Iowa City, IA, USA

EDITORIAL BOARD

Olusegun Baiyewu

Ibadan, Nigeria

Per Bech

Hillered, Denmark

Keri-Leigh Cassidy

Halifax, Canada

Helen Chiu

Hong Kong, China

Jiska Cohen-Mansfield

Tel Aviv, Israel

Yeates Cornwell

Rochester, NY, USA

Devangere P. Devanand

New York, NY, USA

Martin Dichter

Witten, Germany

Alastair J. Flint

Toronto, Canada

Orestes Forlenza

Sao Paulo, Brazil

Martin Haupt

Düsseldorf, Germany

Zahinoor Ismail

Calgary, Canada

Helen C. Kales

Ann Arbor, MI, USA

Dimitris Kiosses

White Plains, NY, USA

Helen Lavretsky

Los Angeles, CA, USA

Raimundo Mateos

Santiago de Compostela, Spain

Kirsten Moore

London, UK

Benoit Mulsant

Toronto, Canada
Cynthia Munro

Baltimore, MD, USA

Ruth O'Hara

Stanford, CA, USA

Nancy A. Pachana

Brisbane, Australia

Kiran Rabheru

Ottawa, Canada

Mark Rapoport

Toronto, Canada

Perminder Sachdev

Randwick, Australia

Ingmar Skoog

Gothenburg, Sweden

Vihang Vahia

Mumbai, India

Johannes Wancata

Vienna, Austria

JUNIOR EDITORIAL BOARD

MEMBERS

Ambrish Dharmadhikari

Mumbai, India

Ellen Lee

San Diego, CA, USA

Maria Marquine

San Diego, CA, USA

Naaheed Mukadam

London, UK

Olga Theou

Halifax, Canada

MANAGING EDITOR

Kate Filipiak

Milwaukee, WI, USA

BOOK REVIEW EDITOR

Barton W. Palmer

La folla, CA, USA

FOUNDER EDITOR

Gene Cohen

Deceased

EDITOR EMERITUS

Robin Eastwood

Bere Ferrers, UK

PAST EDITORS

Gene Cohen

Robin Eastwood

David Ames

Nicola Lautenschlager

EDITORIAL OFFICE

Elaine Halls
Subscriptions

International Psychogeriatrics (ISSN 1041-6102) is published monthly. The annual subscription price (excluding VAT), including delivery by air where appropriate, plus electronic access for subscribers of Volume 30 is $£ 869$ for institutions (US $\$ 1607$ in the USA, Canada and Mexico); the electronic only price available to institutional subscribers is $£ 648$ (US $\$ 1200$ in the USA, Canada and Mexico). For individuals ordering direct from the publisher and certifying that the journal is for their personal use the subscription price (excluding VAT) for print plus electronic access is $£ 366$ (US $\$ 676$ in the USA, Canada and Mexico) or $£ 287$ (US $\$ 531$ in the USA, Canada and Mexico) for electronic only subscriptions. Single issues are $£ 83$ (US $\$ 154$ in the USA, Canada and Mexico) plus postage. Orders, which must be accompanied by payment, may be sent to a bookseller, subscription agent or to the publisher: Cambridge University Press, Journals Fulfillment Department, UPH, Shaftesbury Road, Cambridge CB2 8BS, UK; or in the USA, Canada and Mexico: Cambridge University Press, Journals Fulfillment Department, 1 Liberty Plaza, Floor 20, New York, NY 10006, USA. EU subscribers (outside the UK) who are not registered for VAT should add VAT at their country's rate. VAT registered subscribers should provide their VAT registration number. Japanese prices for institutions are available from: Kinokuniya Company Ltd, PO Box 55, Chitose, Tokyo 156, Japan. Periodicals postage paid at New York, NY, and at additional mailing offices. POSTMASTER: send address changes in USA, Canada and Mexico to: International Psychogeriatrics, Cambridge University Press, Journals Fulfillment Department, 1 Liberty Plaza, Floor 20, New York, NY 10006, USA. Claims for missing issues should be made immediately on receipt of the subsequent issue.

\section{Internet access}

This journal is included in the Cambridge Journals Online service which can be found at journals.cambridge.org/ipg. For further information on other Press titles go to http//www.cambridge.org.

\section{Abstracts}

International Psychogeriatrics is abstracted and indexed in Abstracts in Social Gerontology; Current Literature on Aging; AgeLine; Combined Health Information Database (CHID); Cumulative Index to Nursing \& Allied Health Literature (CINAHL); Current Contents/Social and Behavioral Sciences; EMBASE/Excerpta Medica; e-psyche; Index Medicus/ MEDLINE; ISI Alerting Services; Mental Health Abstracts; New Literature on Old Age; PsychINFO; PsychLIT; Psychological Abstracts; PubMed; Social Sciences Citation Index; Social Services Abstracts; Social Work Abstracts; Sociedad Iberoamericana de Información Cientifica (SIIC) Data Bases; SciSearch and ZeitschriftenbibliographieGerontologie (GeroLIT).

\section{Copying}

This journal is registered with the Copyright Clearance Center, 222 Rosewood Drive, Danvers, MA 01923, USA. Organizations in the USA who are also registered with CCC may therefore photocopy material (beyond the limits permitted by sections 107 and 108 of US Copyright Law) subject to payment to CCC of the per-copy fee of $\$ 16.00$. This consent does not extend to multiple copying for promotional purposes. Code 1041-6102/2017. ISI Tear Sheet Service, 3501 Market Street, Philadelphia, PA 19104, USA, is authorized to supply single copies of separate articles for private use only. Organizations authorized by the UK Copyright Licensing Agency may also photocopy material subject to the usual conditions. For all other use, permission should be sought from Cambridge or the American Branch of Cambridge University Press. No other part of this publication may be reproduced, stored or distributed by any means without permission in writing from Cambridge University Press, acting for the copyright holder.

\section{Acknowledgement}

(Upper left) Seniors jogging on a forest road (C) Kzenon /istockphoto; (Upper right) A Lewy body in a pigmented neuron of the substantia nigra of a Parkinson's disease patient (H/E stain) and (Lower left) tau pathology (green) in the hippocampus of an Alzheimer's disease patient (immunofluorescence) - both images kindly provided by Prof. Johannes Attems, Institute for Ageing and Health, Newcastle University, UK; (Lower right) Senior adults having morning tea together $(\mathbb{C}$ Monkeybusinessimages/istockphoto 